\title{
Androgen Receptor Levels in Cranial Nerve Nuclei and Tongue Muscles in Rats
}

\author{
Wan-hua Amy Yu and Marilyn Y. McGinnis \\ Department of Anatomy, Mount Sinai School of Medicine of The City University of New York, \\ New York, New York 10029
}

\begin{abstract}
Specific in vitro binding of ${ }^{3} \mathrm{H}$-methyltrienolone (R1881) was demonstrated in $100,000 \times g$ supernatant (cytosol) of hypoglossal, facial, and cochlear nuclei and tongue muscles of adult rats. Binding sites in these cranial nerve nuclei and tongue muscles were of high affinity, limited capacity, with steroid specificity; and they were capable of translocation to the cell nuclei in vivo. Accordingly, an androgen receptor system with properties very much akin to the androgen receptors described in the forebrain limbic regions has been quantitatively demonstrated for the first time in brain stem nuclei. Because of its widespread presence in neurons of the brain stem and spinal cord, androgen receptors may have important roles in regulation of neuron physiology beyond the sphere of reproductive function, including mediating androgen effects on regeneration of the hypoglossal nerve reported previously.
\end{abstract}

Neurons responsive to gonadal steroid hormones are most numerous and best known in the forebrain limbic regions such as the hypothalamus, preoptic-septal area, and amygdala. Much evidence has been gathered indicating that gonadal steroids affect the biochemistry (McEwen et al., 1979), electrical activities (Pfaff, 1980), and morphology (Cohen and Pfaff, 1981; Cohen et al., 1984) of neurons in these regions. Some of these effects are thought to be mediated via classical mechanisms of steroid hormone action involving activation of the genome in target cells by hormone-receptor complexes. Recently, it has been demonstrated that gonadal steroid-sensitive neurons are more widely spread. Radioautographic studies in several vertebrate classes have revealed that motor neurons in nuclei of cranial and spinal nerves, as well as neurons of sensory projection areas in the brain stem and spinal cord, concentrate significant amounts of radioactivity following in vivo administration of ${ }^{3} \mathrm{H}$-steroids (Arnold et al., 1976; Breedlove and Arnold, 1980; Commins and Yahr, 1985; Keefer et al., 1973; Kelley, 1980; Kelley et al., 1975; Morrell et al., 1975, 1982; Sar and Stumpf, 1977; Sheridan and Weaker, 1981, 1982). While receptors for gonadal steroids in the forebrain have been measured and characterized, those in the brain stem and spinal cord have not been studied quantitatively.

In the present study, we have measured the levels of androgen receptors in hypoglossal neurons and their target muscles in the tongue. Motor neurons of the facial nerve and cochlear nuclei were included in the study for comparison. An in vitro binding assay developed for measuring androgen receptors in the rat brain and pituitary (McGinnis et al., 1983) was employed, using a synthetic androgen, methyltrienolone (R1881), as ligand. Be-

Received June 17, 1985; revised Sept. 19, 1985; accepted Sept. 23, 1985.

This work was supported by NSF Grant BNS 83-12685.

Correspondence should be addressed to Dr. Yu, Department of Anatomy, Mount Sinai School of Medicine, Fifth Avenue and 100th Street, New York, NY 10029.

Copyright (C) 1986 Society for Neuroscience $0270-6474 / 86 / 051302-06 \$ 02.00 / 0$ cause R 1881 is stable to metabolic conversion and binds weakly to testosterone-estradiol binding globulin (Bonne and Raynaud, 1975, 1976; Doering and Leyra, 1984; Liao et al., 1973), its use was deemed more suitable than its naturally occurring counterparts. The present investigation demonstrates that cranial nerve nuclei and tongue muscles in the adult rat possess a receptor system with properties similar to the androgen receptors described in forebrain regions and limb muscles.

\section{Materials and Methods}

\section{Animals and materials}

Sprague-Dawley rats (200-220 gm) of both sexes were purchased from Charles River Breeding Laboratories (Wilmington, MA). All rats were either orchidectomized or ovariectomized bilaterally under light ether anesthesia $2-3 \mathrm{~d}$ before being killed. ${ }^{3} \mathrm{H}-\mathrm{R} 1881$ (specific activity, $87 \mathrm{Ci}$ / mmol) was purchased from New England Nuclear (Boston, MA). Un labeled steroids and other chemicals were from Sigma Chemical Co. (St. Louis, MO).

\section{Tissue preparation}

Rats were killed by decapitation. The brain stem was quickly removed from the skull and placed, dorsal surface facing upward, on an ice-cold glass plate. Under a dissecting microscope three cuts were made through the brain stem with a razor blade (Fig. 1A). The sections were carefully placed on the cold glass plate and the cochlear $(\mathrm{CN})$, facial $(\mathrm{FN})$, and hypoglossal (HN) nuclei were excised as shown in Figure $1, B$ and $C$. The tonguc was removed by a transvcrse cut ncar the root of the tongue, and placed on an ice-cold glass plate. Tongue muscles were dissected free of extraneous tissues under a dissecting microscope. For the saturation and specificity analyses, tissues from 10-12 rats were pooled for each determination. For single-point assays, tissues from four to six rats were pooled. After dissection, all subsequent procedures were carried out at $0-4^{\circ} \mathrm{C}$.

\section{Cytosol binding assays}

The neural tissue was homogenized in a glass-Teflon homogenizer in $4 \mathrm{vol}$ of TEGDM buffer $(10 \mathrm{~mm}$ Tris- $\mathrm{HCl}, 1.5 \mathrm{~mm}$ EDTA, $10 \% \mathrm{vol} /$ vol glycerol, $1 \mathrm{~mm}$ dithiothreitol, $25 \mathrm{~mm}$ sodium molybdate, $\mathrm{pH} 7.4$ ). The muscle was homogenized in a Polytron homogenizer in 4 vol of TEDGM buffer. Homogenates were centifuged at $100,000 \times g$ for 30 min in a Beckman L2-65B ultracentrifuge. The resulting clear supernatant was retained as cytosol fraction and used for binding assays.

Aliquots of cytosol fraction were pipetted into tubes containing ${ }^{3} \mathrm{H}$ $\mathrm{R} 1881$. For saturation analysis, the final concentration of ${ }^{3} \mathrm{H}-\mathrm{R} 1881$ ranged from 0.25 to $6.0 \mathrm{nM}$. For single-point assays, $3 \mathrm{nM}{ }^{3} \mathrm{H}-\mathrm{R} 1881$ was used. A parallel incubation containing ${ }^{3} \mathrm{H}-\mathrm{R} 1881$ plus unlabeled dihydrotestosterone (DHT) in 100-fold excess was included in all experiments to determine nonspecific binding. The difference between the binding measured in the presence and absence of competing unlabeled DHT represented the specific binding in the tissue sample. Triamcinolone acetonide (TAA) in 100-fold excess was added to all incubates to prevent ${ }^{3} \mathrm{H}-\mathrm{K} 1881$ from binding to glucocorticoid and progestin receptors (Fichman et al., 1981; Hicks and Walsh, 1979). Cytosol and radiolabeled ligand were incubated for $18-24 \mathrm{hr}$ at $0^{\circ} \mathrm{C}$. At the end of 


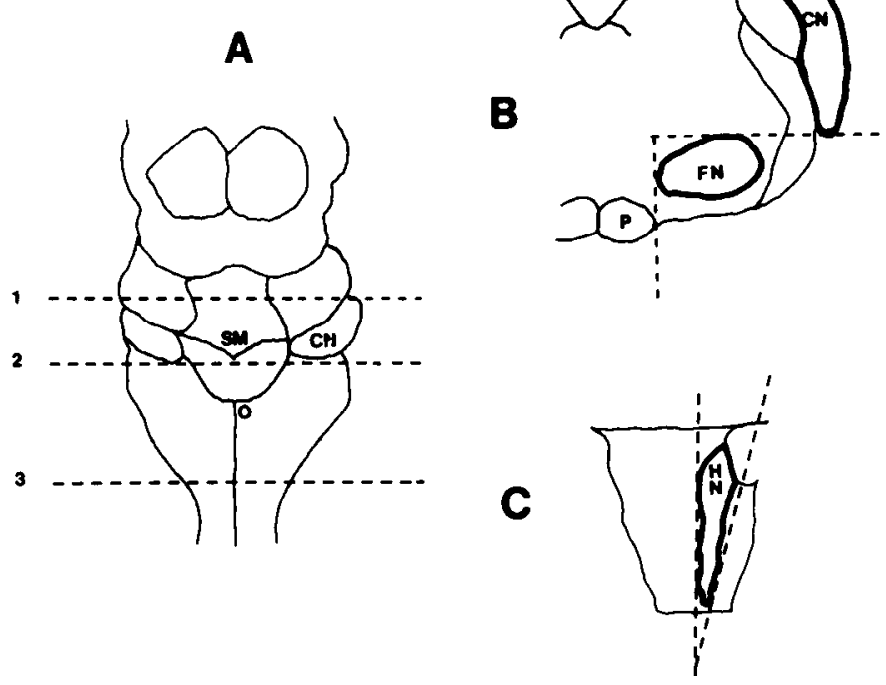

Figure 1. Diagram of rat brain stem showing landmarks used to obtain tissue samples for binding assays. $A$. Dorsal view of brain stem. Cut 1 was made rostral to cochlear nuclei $(C N)$; cut 2 , at the caudal edge of striae medullare $(S M)$; and cut 3, caudal to obex $(O)$. $B$, Posterior surface of the section obtained by cuts 1 and 2. Hatched lines, Areas dissected as facial nuclei $(F N)$. CN were peeled gently apart from the section. $P$, Pyramid; $C$, midsagittal surface of the section obtained by cuts 2 and 3. IIatched lines, Areas dissected as hypoglossal nuclci $(H N)$.

the incubation period, the bound and unbound ${ }^{3} \mathrm{H}-\mathrm{R} 1881$ were separated by filtration through Sephadex LH-20 columns. The radioactivity was determined in a Beckman liquid-scintillation counter at $30 \%$ efficiency. Protein concentration of the cytosol ranged between 0.4 to 1.0 $\mathrm{mg} / \mathrm{ml}$ in neural tissues and between $2-5 \mathrm{mg} / \mathrm{ml}$ in muscles, as determined by the method of Bradford (1976), using BSA as standard.

\section{Translocation of receptors to cell nuclei}

In order to assess whether cytosolic receptors once bound with androgens could be translocated into cell nuclei, a group of castrated rats was injected with $1 \mathrm{mg}$ testosterone propionate (TP) in $0.1 \mathrm{ml}$ propylene glycol $1-2 \mathrm{hr}$ before being killed. Another group of castrated rats injected with $0.1 \mathrm{ml}$ propylene glycol served as controls. Cytosolic and cell nuclear ${ }^{3} \mathrm{H}-\mathrm{R} 1881$ binding were measured separately in rats from the TP-treated and control groups, using single-point assays. Cytosolic R1881 binding was determined by the method described in the preceding section. Cell nuclear R1881 was determined by the exchange assay.

\section{Exchange assays for cell nuclear binding}

Cell nuclei were prepared by homogenizing the tissue in 4 vol of NIIDG buffer containing $1 \mathrm{mM} \mathrm{KH} \mathrm{KO}_{4}, 1 \mathrm{mM} \mathrm{MgCl}, 0.32 \mathrm{M}$ sucrose, $1 \mathrm{~mm}$ dithiothreitol, $10 \% \mathrm{vol} / \mathrm{vol}$ glycerol, $\mathrm{pH} 6.8$. Homogenates were centrifuged at $1000 \times g$ for $5 \mathrm{~min}$ in a Sorvall RC2-B centrifuge. Nuclear pellets were resuspended in NIIDG buffer after two washes with NIIDG buffer. NIIIDG buffer (1 mM $\mathrm{KH}_{2} \mathrm{PO}_{4}, 1 \mathrm{mM} \mathrm{MgCl}_{2}, 2.39$ M sucrose, 1 $\mathrm{mM}$ dithiothreitol, $10 \% \mathrm{vol} / \mathrm{vol}$ glycerol, $\mathrm{pH} 6.8$ ) was added to reach a final sucrose concentration of $2 \mathrm{~m}$. Cell nuclei were pelleted by centrifugation at $25,000 \times g$ for $20 \mathrm{~min}$. The pelleted cell nuclei were resuspended in TEDB buffer ( $10 \mathrm{~mm}$ Tris- $\mathrm{HCl}, 1.5 \mathrm{~mm}$ EDTA, $1 \mathrm{~mm}$ dithiothreitol, $0.5 \mathrm{~mm}$ bacitracin, $\mathrm{pH} 7.4$ ) containing $0.6 \mathrm{M} \mathrm{KCl}$, and nuclear receptor complexes were extracted according to the method of Roy and McEwen (1977). The nuclear suspensions were centrifuged at $25,000 \times g$ for $15 \mathrm{~min}$. Aliquots of salt extracts containing nuclear receptor complexes were incubated with $3 \mathrm{nM}{ }^{3} \mathrm{H}-\mathrm{R} 1881$ with and without 100 -fold excess of unlabeled DHT for $18-24 \mathrm{hr}$ at $0^{\circ} \mathrm{C}$. Bound and unbound ${ }^{3} \mathrm{H}-\mathrm{R} 1881$ were separated by filtration through Sephadex LH20 columns, and radioactivity was determined by liquid-scintillation counting. DNA content in cell nuclei was determined according to the method of Burton (1956). Differences between TP-injected and control groups were evaluated using Student's $t$ test.
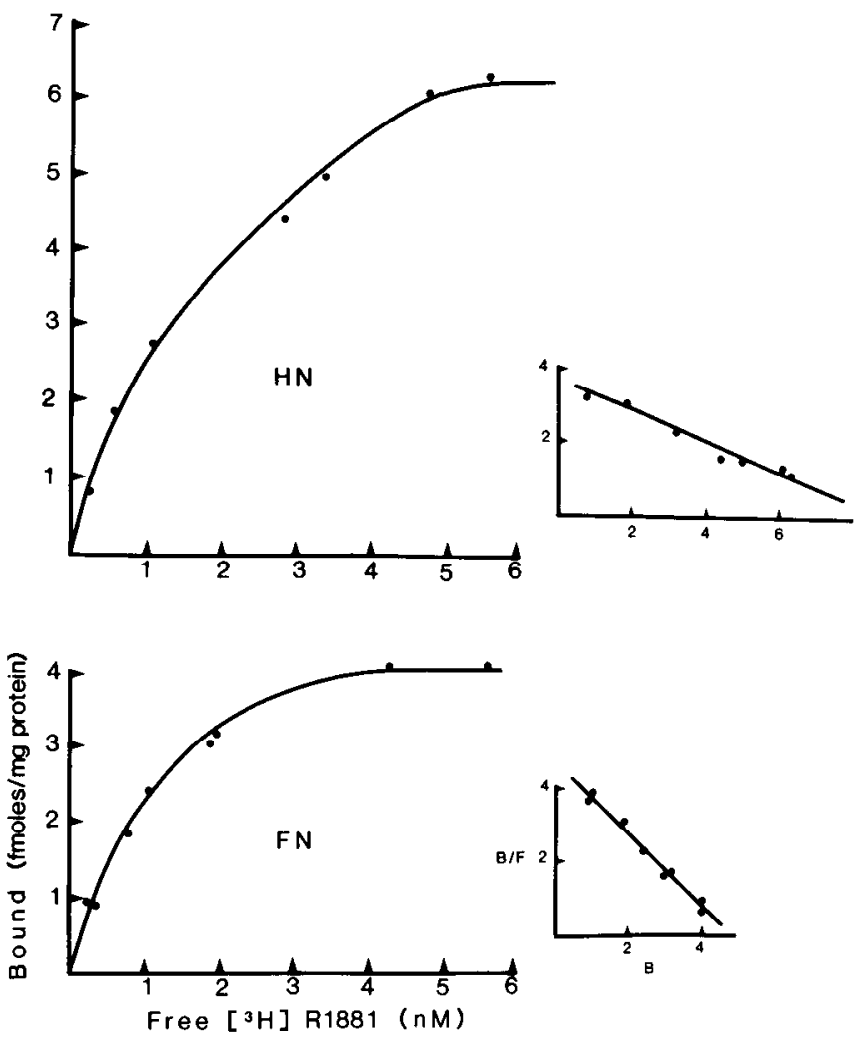

Figure 2. Saturation curves and Scatchard analyses of the binding of ${ }^{3} \mathrm{H}-\mathrm{R} 1881$ to cytosolic receptors. Values are shown for hypoglossal $(H N)$ and facial $(F N)$ nuclei.

\section{Competition studies}

The specificity of ${ }^{3} \mathrm{H}-\mathrm{R} 1881$ binding in cytosol and cell nuclei was tested by incubating aliquots of cytosolic and cell nuclear extracts with a $3 \mathrm{nM}$ concentration of ${ }^{3} \mathrm{H}-\mathrm{R} 1881$ in the presence of unlabeled steroids, DHT, estradiol $\left(\mathrm{E}_{2}\right)$, progesterone $(\mathrm{P})$, and corticosterone $(\mathrm{C})$, at concentrations ranging from $10^{-9}$ to $10^{-6} \mathrm{M}$. TAA in a 100 -fold excess was included in all cytosol competition studies.

\section{Results}

\section{Binding of RI881 in cytosol}

As shown in Figures 2 and 3, saturable, limited-capacity binding sites for ${ }^{3} \mathrm{H}-\mathrm{R} 1881$ were present in the cytosol of hypoglossal nuclei and tongue muscles. A similar binding component for R1881 was also present in the cytosol of cochlear and facial nuclei. The binding capacity derived from Scatchard analysis indicated that hypoglossal nuclei had higher levels of androgen receptors $(8.9 \mathrm{fmol} / \mathrm{mg}$ protein) than either facial $(4.8 \mathrm{fmol} / \mathrm{mg}$ protein) or cochlear nuclei $(4.0 \mathrm{fmol} / \mathrm{mg}$ protein). The binding capacity in tongue muscles was $4.7 \mathrm{fmol} / \mathrm{mg}$ protein. The binding affinities in hypoglossal, facial, and cochlear nuclei, and tongue muscles were $2.5,1.1,1.0$, and $1.1 \mathrm{~nm}$, respectively. All cranial nerve nuclei and tongue muscles had linear Scatchard plots, indicating a single class of high-affinity receptors.

\section{Nuclear translocation of receptors}

Treatment of castrates with $1 \mathrm{mg}$ TP $1-2 \mathrm{hr}$ before being killed resulted in a significant decrease in androgen receptor binding in the cytosol of hypoglossal and facial nuclei and tongue muscles compared to vehicle-injected controls (Fig. 4A). Concomitantly, a highly significant increase in cell nuclear R1881 binding was observed in hypoglossal nuclei of TP-treated rats, which was in great contrast to the absence of nuclear binding of androgens in hypoglossal nuclei of vehicle-injected controls (Fig. 

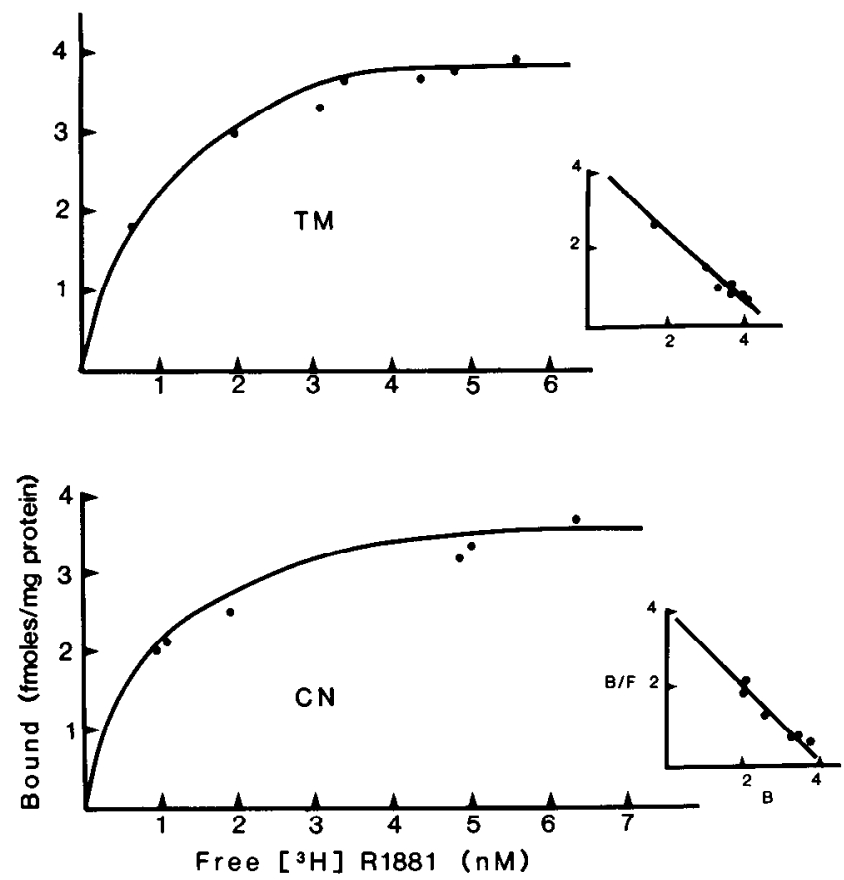

Figure 3. Saturation curves and Scatchard analyses of the binding of ${ }^{3} \mathrm{H}-\mathrm{R} 1881$ to cytosolic receptors. Values are shown for cochlear nuclei $(C N)$ and tongue muscles (TM).

$4 B$ ). Estimates of cell nuclear occupation after TP and estimates of cytosol receptor depletion after TP were in good agreement with each other when expressed per animal rather than per milligram DNA or protein. For the hypoglossal nuclei, cytosol binding decreased by $0.05 \pm 0.01 \mathrm{fmol} / \mathrm{rat}$ after TP, whereas nuclear occupancy incrcased by $0.07 \pm 0.01 \mathrm{fmol} / \mathrm{rat}$. This was based on the assumption that only about half of the nuclear DNA in the nuclear pellet was recovered (McEwen et al., 1972).

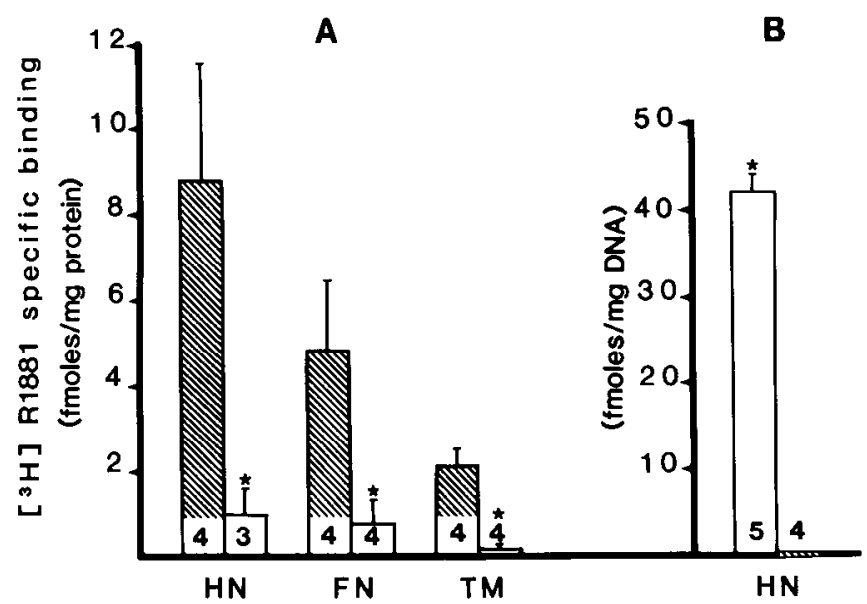

Figure 4. Binding of ${ }^{3} \mathrm{H}-\mathrm{R} 1881$ to cytosolic $(A)$ and nuclear $(B)$ receptors in hypoglossal $(H N)$, facial $(F N)$ nuclei, and tongue muscles $(T M)$ in the presence and absence of circulating androgens. Castrated rats were injected with either $1 \mathrm{mg}$ testosterone propionate (open bars) or vehicle (hatched bars), and androgen receptor binding was assayed 1-2 hr after injection. Androgen receptor binding was measured by procedures described in the text. Results are means with the half-bar representing + SEM. The numbers of determinations are shown at the base of the columns. *, Significantly different from vehicle-injected controls $(p<0.05$; Student's $t$ test).
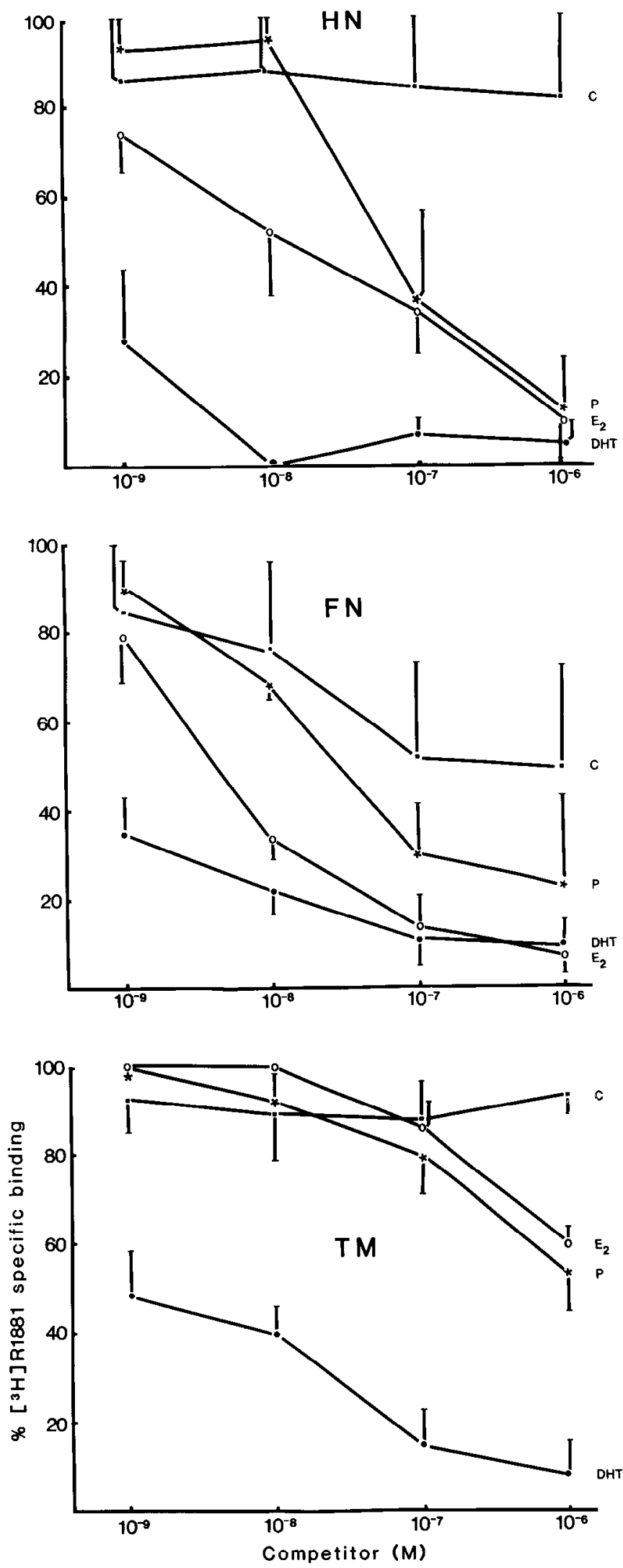

Figure 5. Competition of ${ }^{3} \mathrm{H}-\mathrm{R} 1881$ binding to cytosolic receptors in hypoglossal $(H N)$ and facial $(F N)$ nuclei and tongue muscles $(T M)$ by other steroids. Percentage of specific binding in the presence of dihydrotestosterone $(D H T)$, estradiol $\left(E_{2}\right)$, progesterone $(P)$, and corticosterone $(C)$ at four concentrations is shown. Each data point represents the mean of three to five determinations. 


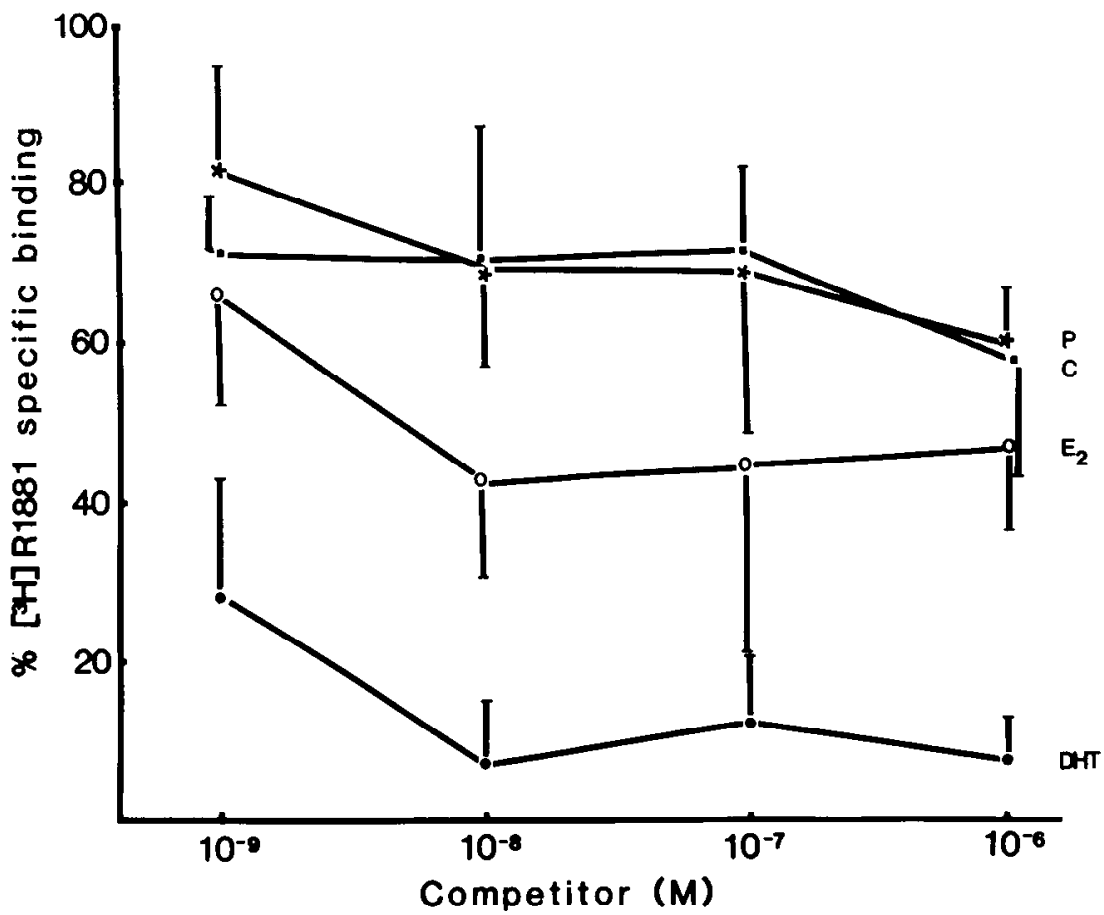

Figure 6. Competition of ${ }^{3} \mathrm{H}-\mathrm{R} 1881$ binding to cell nuclear receptors in hypoglossal nuclei by other steroids. Percentage of specific binding in the presence of dihydrotestosterone $(D H T)$, estradiol $\left(E_{2}\right)$, progesterone $(P)$, and corticosterone $(C)$ is shown. Each data point represents the mean of three to five determinations.

\section{Steroid specificity}

The specificity of high-affinity ${ }^{3} \mathrm{H}-\mathrm{R} 1881$ binding in the cytosol of hypoglossal and facial nuclei and tongue muscles is shown in Figure 5. DHT was the most effective competitor. $\mathrm{E}_{2}$ and $\mathrm{P}$, at higher concentrations, competed for androgen receptor sites in the hypoglossal and facial nuclci, but not in tongue muscles. $\mathrm{C}$ was not a strong competitor for R1881 in any tissue. Figure 6 illustrates the specificity pattern of cell nuclear R1881 binding in hypoglossal nuclei. DHT competed with R1881 for available binding sites. $E_{2}, P$, and $C$ showed little competition for nuclear R 1881 binding sites.

\section{Discussion}

In the present study, we have demonstrated that hypoglossal, facial and cochlear nuclei, and tongue muscles in adult rats contain receptor sites for androgens by in vitro binding assays with the use of a synthetic ligand, R1881. Androgen binding sites in these cranial nerve nuclei and tongue muscles exhibit the characteristics of high affinity, limited capacity, and steroid specificity. Shortly after the administration of TP, the receptor pool in cytosol was depleted, while binding sites in the cell nuclear compartment were substantially increased. These observations are taken to indicate nuclear translocation of receptors, although such an interpretation has recently been questioned (King and Greene, 1984; Welshons et al., 1984). Thus, androgen receptors in these cranial nerve nuclei and tongue muscles qualitatively resemble those found in the forebrain limbic regions and limb muscles. The significance of the presence of androgen receptors in these cranial nerve nuclei remains to be determined. Certain androgen-dependent reproductive behaviors, such as mating, vocalization (Arnold, 1975; Kelley, 1980) and penile reflexes (Hart, 1979), are thought to be mediated by androgen receptors in neurons stationed along the neural pathways controlling these behaviors. However, androgens may affect neuronal function not related to reproductive behaviors.

In previous studies, we have shown that androgens accelerated regeneration of the hypoglossal nerve and facilitated the reinnervation of tongue muscles in rats (Yu, 1982, 1984; $\mathrm{Yu}$ and Srinivasan, 1981; $\mathrm{Yu}$ and $\mathrm{Yu}, 1981,1983)$. Androgens were also reported to hasten reinnervation of leg muscles after sciatic nerve lesion in rabbits (Vita et al., 1983). The site(s) and mechanism(s) whereby androgens influence nerve regeneration are not known at the present time. What has been well documented is that following axotomy the neuronal cell body undergoes a series of structural and biochemical changes indicative of axonal regeneration. Among these changes are increases in the rate of protein synthesis and glucose utilization (Kreutzberg and Emmert, 1980; Singer and Mahler, 1980; Smith et al., 1984). Since a significant adjustment of protein synthetic activity is required of neurons during axonal regeneration, androgen stimulation at the genomic level is a logical step in consideration of its mechanisms of action. The data presented here substantiate our hypothesis that androgens, interacting with specific intracellular receptors, enhance axotomy-induced protein synthetic activity of neurons, even though other mechanisms such as interaction with plasma membrane receptors are also likely to exist (Towle and Sze, 1983).

Smith et al. (1984) reported that the rate of protein synthesis and glucose utilization in the axotomized hypoglossal nucleus remained elevated for an additional 4-14 d after reinnervation of the tongue was established. Consequently, the prolonged elevated metabolic state was thought to encompass both the periods of regeneration of the severed axons and reformation of the functional synapses. It appears that androgens not only promote the initial phase of axonal outgrowth, but also extend their effects into the reinnervation of muscles. This point of view is supported by our observation that testosterone accelerated the return of afferent synapses on the axotomized hypoglossal neurons (Yu and $\mathrm{Yu}, 1981$ ); that the event was reported to occur only after efferent synapses were in place (Rotter et al., 1979; Sumner, 1975) supports this view.

In the present study, we have shown that the tongue musculature contains androgen binding sites that are qualitatively similar to those in hindlimb and levator ani muscles of rats (Hickson et al., 1983; Max, 1981; Max et al., 1981; Snochowski et al., 1980; Tremblay et al., 1977). However, the androgen binding capacity of the tongue muscles is closer to that described in the limb muscles $(1.5-3.0 \mathrm{fmol} / \mathrm{mg}$ protein) than in the perineal muscles (8.0-11.7 fmol/mg protein). To our knowledge, 
this is the first report on the presence of androgen receptors in the skeletal muscles of the cranial area. Our data suggest that androgen receptors in neurons as well as in muscles could participate in mediating androgenic effects on nerve regeneration. Denervation or disuse of the limb and perineal muscles has been reported to raise significantly the levels of androgen, as well as glucocorticoid receptors (Bernard et al., 1984; DuBois and Almon, 1980, 1981). Whether a similar phenomenon occurs in the tongue muscles after denervation has not been investigated. Another open question awaiting elucidation is the target site of androgen action, that is, whether androgens exert their effect on neurons, muscles, or both.

An unexpected finding was the presence of androgen receptors in the cochlear nuclei. Cochlear nuclei were intended as a negative control for the binding assays on the basis of the reported absence of androgen-concentrating neurons in this nucleus in radioautography (Sar and Stumpf, 1977). Since the cochlear nuclei have the lowest androgen binding capacity when compared to brain stem motor nuclei or the forebrain limbic regions (11.6 fmol/mg protein) and cerebral cortex $(4.7 \mathrm{fmol} / \mathrm{mg}$ protein) reported previously (McGinnis et al., 1983), the duration of the exposure time routinely utilized for radioautography may not be long enough to reveal uptake of the labeled steroid. To our knowledge, steroid-concentrating neurons in the auditory system have been reported only in frogs (Kelley, 1980; Kelley et al., 1975; Morrell et al., 1975). Since neurons in the auditory system in frogs accumulate both DHT and estrogen, we sought to measure estrogen binding sites in the rat cochlear nuclei. Contrary to expectation, the cytosolic estrogen receptor level in cochlear nuclei was negligible (data not shown). Steroid hormones were thought to modulate auditory sensitivity in frogs to conspecific vocalization during the breeding season (Kelley, 1980 ). Whether androgens subserve a similar function in rodents remains to be determined. Ultrasonic vocalizations were reported to occur commonly during social interactions among young and adult rodents (Barfield et al., 1979; Colvin, 1973; Sales and Smith, 1978; Watts, 1975), and it is likely that androgen receptors in cochlear nuclei may play important roles in communicatory functions.

In conclusion, an androgen receptor system has been demonstrated in adult rat cranial nerve nuclei and tongue muscles. Our results substantiate previous autoradiographic findings that alluded to the widespread presence of nuclear receptors for androgens in motor ncurons. Since motor neurons have also been shown to contain nuclear receptors for corticosterone (Duncan and Stumpf, 1984), it appears that motor neurons may be under extensive regulation by steroid hormones. Although our understanding of the effect of steroid hormones on motor neurons is meager, the emerging body of information suggests that these hormones have important roles in the regulation of motor neurons beyond those involved in reproductive functions.

\section{References}

Arnold, A. P. (1975) The effects of castration and androgen replacement on song, courtship, and aggression in zebra finch (Poephila guttata). J. Exp. Zool. 191: 309-326.

Arnold, A. P., F. Nottebohm, and D. W. Pfaff (1976) Hormone concentrating cells in vocal control and other brain regions of the zebra finch (Poephila guttata). J. Comp. Neurol. 165: 487-512.

Barfield, R. J., P. Auerbach, L. A. Geyer, and T. K. McIntosh (1979) Ultrasonic vocalizations in rat sexual behavior. Am. Zool. 19: 469480.

Bernard, P. A., N. E. Rance, P. S. Fishman, and S. R. Max (1984) Increased cytosolic androgen receptor binding in rat striated muscle following denervation and disuse. J. Neurochem. 43: 1479-1483.

Bonne, C., and J. P. Raynaud (1975) Methyltrienolone, a specific ligand for cellular androgen receptors. Steroids $26: 227-232$.

Bonne, C., and J. P. Raynaud (1976) Assay of androgen binding sites by exchange with methyltrienolone (R1881). Steroids 27: 497-507.

Bradford, M. M. (1976) A rapid and sensitive method for quantitation of microgram quantities of protein utilizing the principle of protein dye binding. Anal. Biochem. 72: 248-254.

Breedlove, S. M., and A. P. Arnold (1980) Hormone accumulation in sexually dimorphic motor nucleus of the rat spinal cord. Science 210 : 564-566.

Burton, K. (1956) A study of the conditions and mechanisms of the diphenylamine reaction for colorimetric estimation of DNA. Biochem. J. 62: 315-323.

Cohen, R. S., and D. W. Pfaff (1981) Ultrastructure of neurons in the ventromedial nucleus of the hypothalamus in ovariectomized rats with or without estrogen treatment. Cell Tissue Res. 217: 451-470.

Cohen, R. S., S. K. Chung, and D. W. Pfaff (1984) Alteration by estrogen of the nucleoli in nerve cells of the rat hypothalamus. Cell Tissue Res. 235: 485-489.

Colvin, M. A. (1973) Analysis of acoustic structure and function in ultrasounds of neonatal Microtus. Behaviour 44: 234-263.

Commins, D., and P. Yahr (1985) Autoradiographic localization of estrogen and androgen receptors in the sexually dimorphic area and other regions of the gerbil brain. J. Comp. Neurol. 231: 473-489.

Doering, C. H., and P. T. Leyra (1984) Methyltrienolone (R1881) is not aromatized by placental microsomes of rat hypothalamic homogenates. J. Steroid Biochem. 20: 1157-1162.

DuBois, D. C., and R. R. Almon (1980) Disuse atrophy of skeletal muscle is associated with an increase in number of glucocorticoid receptors. Endocrinology 107: 1649-1651.

DuBois, D. C., and R. R. Almon (1981) A possible role for glucocorticoids in denervation atrophy. Muscle Nerve 4: 370-373.

Duncan, G., and W. E. Stumpf (1984) Target neurons for $\left[{ }^{3} \mathrm{H}\right]$ corticosterone in the rat spinal cord. Brain Res. 307: 321-326.

Fichman, K. R., L. M. Nyberg, P. Bujnovsky, T. R. Brown, and P. C. Walsh (1981) The ontogeny of the androgen receptor in human foreskin. J. Clin. Endocrinol. Metab. 52: 919-923.

Hart, B. L. (1979) Activation of sexual reflexes of male rats by dihydrotestosterone but not estrogen. Physiol. Behav. 23: 107-109.

Hicks, L. L., and P. C. Walsh (1979) A microassay for the measurement of androgen receptors in human prostatic tissue. Steroids 33: 389-406.

Hickson, R. C., T. M. Galassi, T. T. Kurowski, D. G. Daniels, and R. T. Chatterton, Jr. (1983) Skeletal muscle cytosol $\left[{ }^{3} \mathrm{H}\right]$ methyltrienolone receptor binding and serum androgens: Effects of hypertrophy and hormonal state. J. Steroid Biochem. 19: 1705-1712.

Keefer, D. A., W. E. Stumpf, and M. Sar (1973) Estrogen-topographical localization of estrogen-concentrating cells in the rat spinal cord following ${ }^{3} \mathrm{H}$-estradiol administration. Proc. Soc. Exp. Biol. Med. 143: 414-417.

Kelley, D. B. (1980) Auditory and vocal nuclei in the frog brain concentrate sex hormones. Science 207: 553-555.

Kelley, D. B., J. I. Morrell, and D. W. Pfaff (1975) Autoradiographic localization of hormone-concentrating cells in the brain of an amphibian, Xenopus laevis. I. Testosterone. J. Comp. Neurol. 164: 4762.

King, W. J., and G. L. Greene (1984) Monoclonal antibodies localize oestrogen receptor in the nuclei of target cells. Nature 307: 745-747.

Kreutzberg, G. W., and H. Emmert (1980) Glucose utilization of motor nuclei during regeneration: $\mathrm{A}\left({ }^{14} \mathrm{C}\right) 2$-deoxyglucose study. Exp. Neurol. 70: 712-716.

Liao, S., T. Liang, S. Fang, E. Castaneda, and T. C. Shao (1973) Steroid structure and androgenic activity: Specificities involved in the receptor binding and nuclear retention of various androgens. J. Biol. Chem. 248: 6154-6162.

Max, S. R. (1981) Cytosolic androgen receptor in skeletal muscle from normal and testicular feminization mutant (Tfm) rats. Biochem. Biophys. Res. Commun. 101: 792-799.

Max, S. R., S. Mufti, and B. M. Carlson (1981) Cytosolic androgen receptor in regenerating rat levator ani muscle. Biochem. J. 200:7782.

McEwen, B. S., L. Plapinger, G. Wallach, and C. Magnus (1972) Properties of cell nuclei isolated from various regions of rat brain: Divergent characteristics of cerebellar cell nuclei. J. Neurochem. 19: 11591170.

McEwen, B. S., P. G. Davis, B. Parsons, and D. W. Pfaff (1979) The brain as a target for steroid hormone action. Annu. Rev. Neurosci. 2: $65-112$.

McGinnis, M. Y., P. G. Davis, M. J. Meaney, M. Singer, and B. S. McEwen (1983) In vitro measurement of cytosol and cell nuclear 
androgen receptors in male rat brain and pituitary. Brain Res. 275 : $75-82$.

Morrell, J. I., D. B. Kelley, and D. W. Pfaff (1975) Autoradiographic localization of hormone-concentrating cells in the brain of an amphibian, Xenopus laevis. II. Estradiol. J. Comp. Neurol. 164: 63-78.

Morrell, J. I., T. D. Wolinsky, M. S. Krieger, and D. W. Pfaff (1982) Autoradiographic identification of estradiol-concentrating cells in the spinal cord of the female rat. Exp. Brain Res. 45: 144-150.

Pfaff, D. W. (1980) Estrogens and Brain Function, Springer-Verlag, New York.

Rotter, A., N. J. M. Birdsall, A. S. V. Burgen, P. M. Field, A. Smolen, and G. Raisman (1979) Muscarinic receptors in the central nervous system of the rat. IV. A comparison of the effects of axotomy and deafferentation on the binding of $\left[{ }^{2} \mathrm{H}\right]$ propylbenzilycholine mustard and associated synaptic changes in the hypoglossal and pontine nuclei Brain Res. Rev. 1: 207-224.

Roy, E. J., and B. S. McEwen (1977) An exchange assay for estrogen receptors in cell nuclei of the adult rat brain. Steroids 30:657-669.

Sales, G. D., and J. C. Smith (1978) Comparative studies of the ultrasonic calls of infant murid rodents. Dev. Psychobiol. 11: 595-619.

Sar, M., and W. E. Stumpf (1977) Androgen concentration in motor neurons of cranial nerves and spinal cord. Scicnce 197: 77-79.

Sheridan, P. J., and F. J. Weaker (1981) The primate spinal cord is a target for gonadal steroids. J. Neuropathol. Exp. Neurol. 40:447453.

Sheridan, P. J., and F. J. Weaker (1982) Androgen receptor systems in the brain stem of the primate. Brain Res. 235: 225-232.

Singer, P. A., and S. Mahler (1980) 2-Deoxy $\left({ }^{14} \mathrm{C}\right)$ glucose uptake in the rat hypoglossal nucleus after nerve transection. Exp. Neurol. 69 617-626.

Smith, C. B., A. M. Crane, M. Kadekaro, B. W. Agranoff, and L. Sokoloff (1984) Stimulation of protein synthesis and glucose utilization in the hypoglossal nucleus induced by axotomy. J. Neurosci. 4: 2489-2496.
Snochowski, M., E. Dahlberg, and J.-A. Gustafsson (1980) Characterization and quantification of the androgen and glucocorticoid receptors in cytosol from rat skeletal muscle. Eur. J. Biochem. 111: 603-616.

Sumner, B. E. H. (1975) A quantitative analysis of the response of presynaptic boutons to postsynaptic motor neuron axotomy. Exp. Neurol. 46: 605-615.

Towle, A. C., and P. Y. Sze (1983) Steroid binding to synaptic plasma membrane: Differential binding of glucocorticoids and gonadal steroids. J. Steroid Biochem. 18: 135-143.

Tremblay, R. R., J. Y. Dube, M. A. Ho-Kim, and R. Lesage (1977) Determination of rat muscles androgen-receptor complexes with methyltrienolone. Steroids 29: 185-195.

Vita, G., R. Dattola, P. Girlanda, G. Oteri, F. Lo Presti, and C. Messina (1983) Effects of steroid hormones on muscle reinnervation. Exp. Neurol. 80: 279-287.

Watts, C. H. S. (1975) Vocalizations of Australian hopping mice (Rodentia Notomys). J. Zool. Lond. 177: 247-263.

Welshons, W. V., M. E. Lieberman, and J. Gorski (1984) Nuclear localization of unoccupied oestrogen receptors. Nature 307:747-749.

$\mathrm{Yu}$, W. H. A. (1982) Effect of testosterone on the regeneration of the hypoglossal nerve in rats. Exp. Neurol. 77: 129-141.

Yu, W. H. A. (1984) Responsiveness of hypoglossal neurons to testosterone in pre-pubertal rats. Brain Res. Bull. 13: 667-672.

Yu, W. H. A., and R. Srinivasan (1981) Effect of testosterone and 5 $\alpha-$ dihydrotestosterone on regeneration of the hypoglossal nerve in rats. Exp. Neurol. 71: 431-435.

Yu, W. H. A., and M. C. Yu (1981) Accelerated restoration of central synapses on chromatolytic neurons by testosterone. Anat. Rec. 199. $286 \mathrm{~A}$.

Yu, W. H. A., and M. C. Yu (1983) Acceleration of the regeneration of the crushed hypoglossal nerve by testosterone. Exp. Neurol. 80: $349-360$. 